\title{
Matgorzata Stępień
}

\section{MALARIA IN POLAND IN 2014 - 2018*}

\author{
MALARIA W POLSCE W LATACH 2014 - 2018*
}

National Institute of Public Health - National Institute of Hygiene in Warsaw

Department of Epidemiology of Infectious Diseases and Surveillance

Narodowy Instytut Zdrowia Publicznego - Państwowy Zakład Higieny

Zakład Epidemiologii Chorób Zakaźnych i Nadzoru

\begin{abstract}
OBJECTIVE. Assessment of the epidemiological situation of imported malaria in Poland in 2014-2018 in comparison with the situation in previous years.

MATERIAL AND METHODS. The analysis of data on malaria cases included in individual reports sent to the Department of Epidemiology of NIPH-NIH by sanitary-epidemiological stations and aggregate data published in annual bulletins "Infectious diseases and poisonings in Poland" was carried out. Reported cases were classified according to the criteria of the case definition applicable in EU countries (2012/506 / EU).

RESULTS. In 2014-2018, a total of 141 cases of malaria were registered in Poland, all cases were imported from malaria-endemic countries. The lowest number of cases reported in 2014 (19 cases), and the highest in 2016 (38 cases), the median number of cases in the period 2014-2018 was 28 and was by $27 \%$ higher than in the previous 5 -year period. The incidence in the observed period was 0.7 per 1 million population and case fatality rate $3.6 \%$ ( 5 deaths per 140 cases with known outcome). Patients were aged 18-74 years, median age was 38 years, males accounted for $72 \%$ of all patients. In $89 \%$ of cases, infection was acquired in African countries and Cameroon was the most frequently mentioned among countries of exposure. Species of Plasmodium was determined in $90 \%$ of invasions, of which P. falciparum accounted for $78 \%$. Most of malaria patients registered in Poland travelled for tourism/leisure $(45 \%, 56 / 124)$ or business $(43 \%, 53 / 124)$. People visiting the country of origin (visiting friends and relatives, VFR) accounted for $10 \%$ of patients for whom the purpose of the trip was known. The mean time of diagnostic delay between the onset of symptoms and the diagnosis was 6 days.

CONCLUSIONS. In recent years, there has been an increase in the number of malaria cases in Poland compared to previous years, but the total number of cases remains low. After a few years of low fatality rate, the number of deaths due to malaria increased again, likewise the number of cases with diagnostic delays ( $>3$ days after the onset of symptoms) and severe disease. The obtained data indicate the need to strengthen activities that raise the awareness of travellers on available prophylaxis and need to remind primary healthcare doctors about an extended anamnesis including travel history and the consideration of malaria in diagnosing of a febrile patient.
\end{abstract}

Keywords: imported malaria, epidemiology, Poland, 2014-2018

\section{STRESZCZENIE}

CEL. Ocena sytuacji epidemiologicznej malarii w Polsce w latach 2014-2018 w porównaniu z sytuacją w poprzednich latach.

MATERIAL I METODY. Analizowano dane o zachorowaniach zawarte w indywidualnych raportach przesyłanych do Zakładu Epidemiologii Chorób Zakaźnych i Nadzoru NIZP-PZH przez stacje sanitarno-epidemiologiczne oraz dane zbiorcze publikowane w Biuletynach rocznych „Choroby zakaźne i zatrucia w Polsce”. Zgłoszone zachorowania klasyfikowano zgodnie z kryteriami definicji przypadku obowiązującej w krajach EU (2012/506/UE). WYNIKI. W latach 2014-2018 zarejestrowano w Polsce 141 zachorowań na malarię, wszystkie przypadki zostały zawleczone z krajów endemicznego występowania malarii. Najniższą liczbę zachorowań odnotowano w 2014 r. (19 przypadków), a najwyższą w 2016 (38), mediana liczby zachorowań w latach 2014-2018 wynosiła 28 i była o 27\% wyższa niż w poprzednim okresie 5-letnim. Zapadalność w obserwowanym okresie wynosiła 0,7/1 mln mieszkańców, śmiertelność - 3,6\% (5/140 zachorowań o znanym zejściu). Chorowały osoby w wieku 18-74 lata, mediana wieku wynosiła 38

*Article was written under the task No. 7/EM.1/2018 / *Praca została wykonana w ramach zadania nr 7/EM.1/2018

(C) National Institute of Public Health - National Institute of Hygiene / Narodowy Instytut Zdrowia Publicznego - Państwowy Zakład Higieny 
lat, mężczyźni stanowili 72\% wszystkich chorych. W 89\% przypadków do zarażenia doszło w krajach Afryki - wśród krajów narażenia najczęściej wymieniany był Kamerun. Gatunek Plasmodium określono w 90\% inwazji, w tym P. falciparum stanowił 78\%. Większość chorych zarejestrowanych w Polsce podróżowała turystycznie $(45 \%, 56 / 124)$ lub w związku z pracą $(43 \%, 53 / 124)$. Osoby odwiedzające kraj pochodzenia stanowily $10 \%$ chorych, dla których znany był cel podróżowania. Średni czas opóźnienia rozpoznania od początku objawów wynosił 6 dni.

WNIOSKI. W ostatnich latach odnotowano w Polsce wzrost liczby zawleczeń malarii w porównaniu z poprzednimi latami, jednak całkowita liczba zachorowań pozostaje niska. Po kilkuletnim okresie niskiej śmiertelności ponownie odnotowano wzrost liczby przypadków śmiertelnych oraz zwiększenie odsetka zachorowań z opóźnionym rozpoznaniem ( $>3$ dni od wystąpienia objawów) oraz o ciężkim przebiegu. Uzyskane dane wskazują na konieczność wzmocnienia działań podnoszących świadomość osób podróżujących w zakresie dostępnej profilaktyki oraz przypominania lekarzom POZ o rozszerzonym wywiadzie obejmującym podróże i uwzględnianiu malarii w diagnostyce stanów gorączkowych.

Slowa kluczowe: malaria (zimnica), epidemiologia, Polska, lata 2014-2018

\section{INTRODUCTION}

Malaria is a notifiable disease under the European TESSy system. In the EU / EEA malaria notification rate maintained at a relatively stable level for many years, at around 1 per 100000 population (in 2016, 8,225 confirmed cases were registered, 1.2 / 100,000 population, excluding overseas territories or departments) (1).

$99.8 \%$ of confirmed cases are imported, however, as of 2009, the number of reports on non-travel related cases is increasing - these are both sporadic cases related to the importation of infected mosquitoes (luggage / airport malaria) and infections as a result of local mosquito-borne malaria transmission (most in Greece), and in recent years also nosocomial/ iatrogenic infections (2). These latter cases were particularly worrisome in connection with the malaria acquired during stay in the hospital in three children, including one case with fatal outcome (two children in Italy, one of whom died and one in Spain) (3). In 2016, there were a total of 11 cases locally-acquired: six reported by Greece, two by France, and one P. falciparum case each by: Spain, Germany and Lithuania. Cases were classified as introduced malaria (mosquito-borne transmission from an imported malaria case), airport malaria or nosocomial (vector-borne or iatrogenic), local transmission was not recognized (1).

In 2017, 13 locally acquired cases were reported: six again in Greece, three in Cyprus (UK citizens), two in France, two in Italy. It was probable, that two of these cases have been acquired as iatrogenic (without relation to the transfusion) (2). In 2018 (incomplete data) there were 9 cases of introduced malaria in Greece and 1 case of nosocomial malaria (in infant) in Spain.

In addition, in Western European countries there is still a problem of a large number of cases among migrants visiting relatives and friends (VFR) in the country of origin. While the situation of immigrants from sub-Saharan countries staying in Europe for many years is well recognized and included in healthcare

\section{WPROWADZENIE}

Malaria jest chorobą podlegającą zgłaszaniu w ramach europejskiego systemu TESSy, w krajach EU/ EEA zapadalność na malarię utrzymuje się od wielu lat na względnie stałym poziomie ok. 1/100 tys. mieszkańców (w 2016 r. zarejestrowano 8225 potwierdzonych przypadków, zapadalność 1,2/100 tys., bez uwzględnienia terytoriów zamorskich) (1).

Przypadki importowane stanowią 99,8\% potwierdzonych zachorowań, jednak począwszy od $2009 \mathrm{r}$. zwiększa się liczba doniesień o występowaniu zachorowań niezwiązanych z podróżami - są to zarówno zachorowania sporadyczne związane $\mathrm{z}$ importem zarażonych komarów (luggage/airport malaria). jak i zachorowania w wyniku rodzimej transmisji malarii (najwięcej w Grecji), a w ostatnich latach także zarażenia szpitalne/jatrogenne (2). Te ostatnie przypadki wzbudziły szczególny niepokój w związku z zarażeniem malarią trojga dzieci przebywających w szpitalu, w tym jednego ze skutkiem śmiertelnym (dwoje dzieci we Włoszech, z których jedno zmarło, jedno w Hiszpanii) (3). W 2016 r. odnotowano ogółem 11 zachorowań nabytych lokalnie: sześć w Grecji, dwa we Francji, i po jednym w Hiszpanii, w Niemczech i na Litwie. Przypadki sklasyfikowano jako malarię wprowadzoną (ukłucie przez komara zarażonego lokalnie od osoby z malarią zawleczoną), lotniskową lub szpitalną, nie rozpoznano lokalnej transmisji (1). W 2017 r. zgłoszono 13 zachorowań nabytych lokalnie: ponownie sześć w Grecji, trzy na Cyprze (obywatele UK), dwa we Francji, dwa we Włoszech. Dwa z wymienionych zachorowań mogły być nabyte jatrogennie (bez związku z transfuzją) (2). W 2018 r. (dane niepełne) w Grecji ponownie wystąpiło 9 przypadków malarii wprowadzonej oraz 1 przypadek malarii szpitalnej (u niemowlęcia) w Hiszpanii.

Dodatkowo, w krajach Europy Zachodniej nadal istnieje problem dużej liczby zachorowań wśród migrantów odwiedzających krewnych i znajomych w kraju pochodzenia. O ile sytuacja imigrantów z krajów subsaha- 
programs (educational activities and chemoprophylaxis available for travellers), recent immigrants who are usually asymptomatic with low parasitaemia, may be an actual problem of public health. In recently arrived immigrants, parasites may persist in the blood for over 20 months after arrival, acting as a reservoir for locally occurring mosquitoes as well as a threat to infected people, especially pregnant women, in whom malaria may be transmitted to the foetus vertically (4).

The data reported above indicate a direct risk of restoring autochthonous transmission in European malaria-free countries, including in Poland (where the risk is limited to $P$. vivax for climatic reasons).

\section{MATERIAL AND METHODS}

The assessment of the epidemiological situation of malaria in Poland in 2014-2018 was based on the results of analysis of individual case reports on malaria sent to Department of Epidemiology NIPH-NIH by sanitaryepidemiological stations (reports from 2014-2017) and on data from annual bulletins "Infectious diseases and poisonings in Poland" for the years 2014 - 2017 (5). Since 2018, complete data on individual malaria cases have been registered in the national Epidemiological Interview Registration System (SRWE) kept in NIPHNIH. The assessment of epidemiological situation of malaria in Poland in previous years was also used (6).

In the period 2014-2018 recorded malaria cases that occurred in Poland (7) and met the case definition adopted by the European Commission decision of 8 August 2012 (2012/506 / EU). In the years 2014-2018, the case definition remained unchanged and did not differ from the definition introduced in 2008 (8). As a confirmed case was classified any person meeting the clinical and the laboratory criteria i.e. person with fever or history of fever and demonstration of malaria parasites in blood films, or a nucleic acid or a Plasmodium antigen in blood. According to the case definition, if possible, differentiation of Plasmodium species should be performed.

\section{RESULTS}

In 2014-2018, a total of 141 malaria cases were registered in Poland. The number of cases per year ranged from 19 in 2014 to 38 in 2016 (Table 1), and the incidence ranged from $0.5 / 1$ million population in 2014 to $1 / 1$ million population in 2016 . The number of cases registered in 2016 ( 38 cases) reached the highest value in the last 20 years, similar values were noted in the past only in 1997 and 1998 ( 37 and 38 cases, respectively). The median number of cases in 2014-2018 was 28, compared to 22 in the previous 5-year period (2009-2013), which means an increase by $27 \%$ compared to the median in 2009-2013. ryjskich przebywających w Europie od wielu lat jest dobrze rozpoznana i uwzględniana w programach opieki zdrowotnej (działania edukacyjne i chemioprofilaktyka dostępna dla wyjeżdżających), to problemem zdrowia publicznego mogą być niedawno przybyli imigranci zarażeni bezobjawowo, zwykle z niskim poziomem parazytemii. U nowo przybyłych imigrantów zarodźce mogą przetrwać we krwi nawet ponad 20 miesięcy, stanowiąc zarówno rezerwuar dla lokalnie występujących komarów, jak i zagrożenie dla osób zarażonych, szczególnie kobiet w ciąży, u których może dojść do przekazania malarii płodowi na drodze wertykalnej (4).

Przytoczone dane wskazują na bezpośrednie ryzyko przywrócenia transmisji malarii w krajach, w których została ona wyeliminowana, $w$ tym również w Polsce (ze względów klimatycznych w zakresie ograniczonym do $P$. vivax).

\section{MATERIAŁ I METODY}

Oceny sytuacji epidemiologicznej malarii w Polsce w latach 2014-2018 dokonano na podstawie wyników analizy raportów jednostkowych o zachorowaniach na malarię nadesłanych do Zakładu Epidemiologii Chorób Zakaźnych i Nadzoru NIZP-PZH przez stacje sanitarno-epidemiologiczne (raporty z lat 2014-2017) oraz analizy danych z biuletynów rocznych „Choroby zakaźne i zatrucia w Polsce" za lata 2014 - 2017 (5). Od 2018 r. pełne dane o indywidualnych zachorowaniach na malarię są rejestrowane w krajowym elektronicznym Systemie Rejestracji Wywiadów Epidemiologicznych (SRWE) prowadzonym w NIZP-PZH. Korzystano również z opisów sytuacji epidemiologicznej malarii w Polsce w poprzednich latach (6).

W analizowanym okresie 2014-2018 r. rejestrowano zachorowania na malarię, które wystąpiły na terenie Polski (7) i spełniały kryteria definicji przypadku przyjętej przez Komisję Europejską w decyzji z dnia 8 sierpnia 2012 r. (2012/506/UE). W okresie 2014-2018 stosowana definicja przypadku nie uległa zmianie i nie różniła się w stosunku do definicji wprowadzonej w 2008 r.(8). Za przypadek potwierdzony uznawano każdą osobę z gorączką lub gorączką w wywiadzie, u której wykazano obecność zarodźców malarii w rozmazach krwi metodą mikroskopii świetlnej, lub wykryto we krwi kwas nukleinowy lub antygen Plasmodium. Zgodnie z definicją przypadku, jeżeli to możliwe, należy wykonać różnicowanie w obrębie rodzaju Plasmodium.

\section{WYNIKI}

W latach 2014-2018 w Polsce zarejestrowano ogółem 141 zachorowań na malarię. Liczba zachorowań rejestrowanych rocznie wahała się od $19 \mathrm{w} 2014$ r. do 38 w 2016 r. (Tab. I), a zapadalność wynosiła od 0,5/1 mln ludności w 2014 r. do 1/1 mln mieszkańców w 2016 r. 


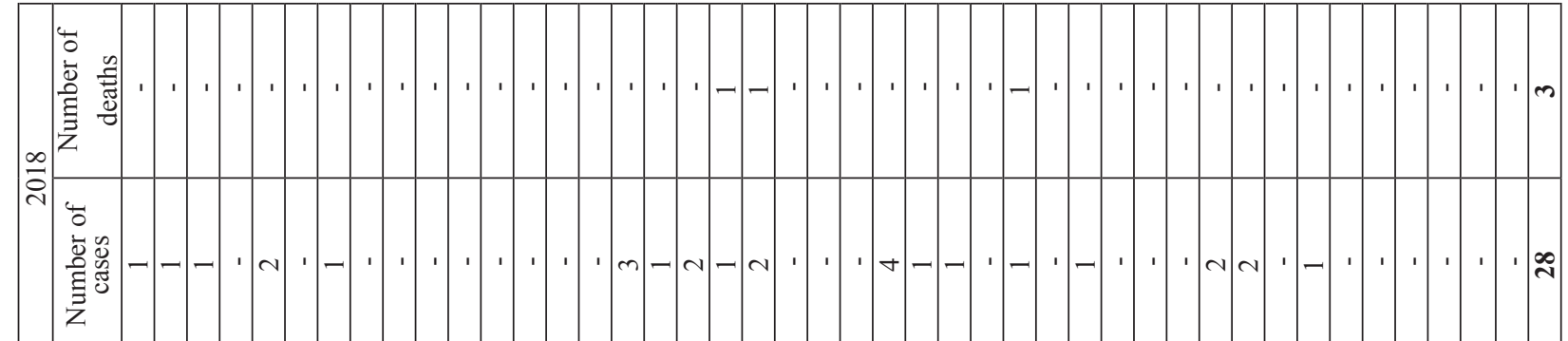

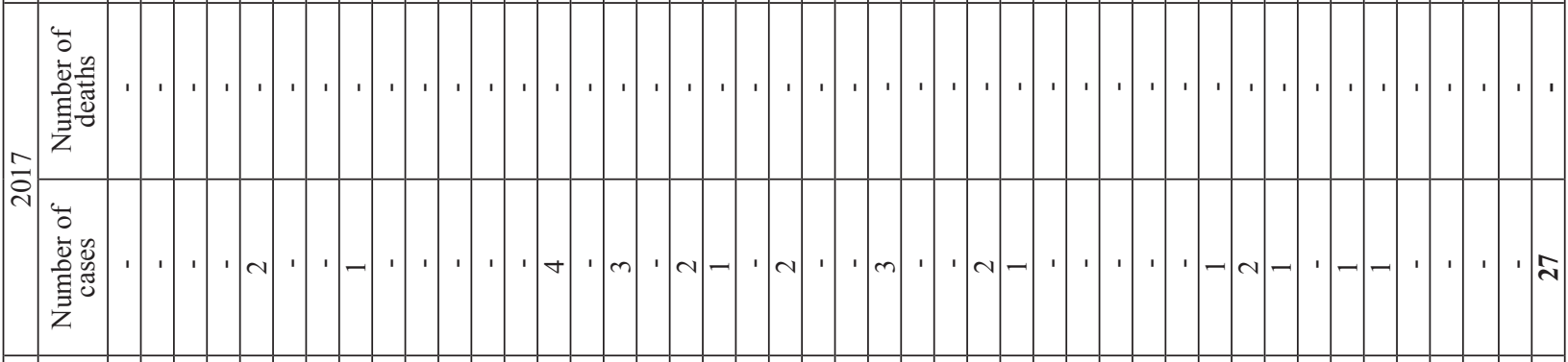

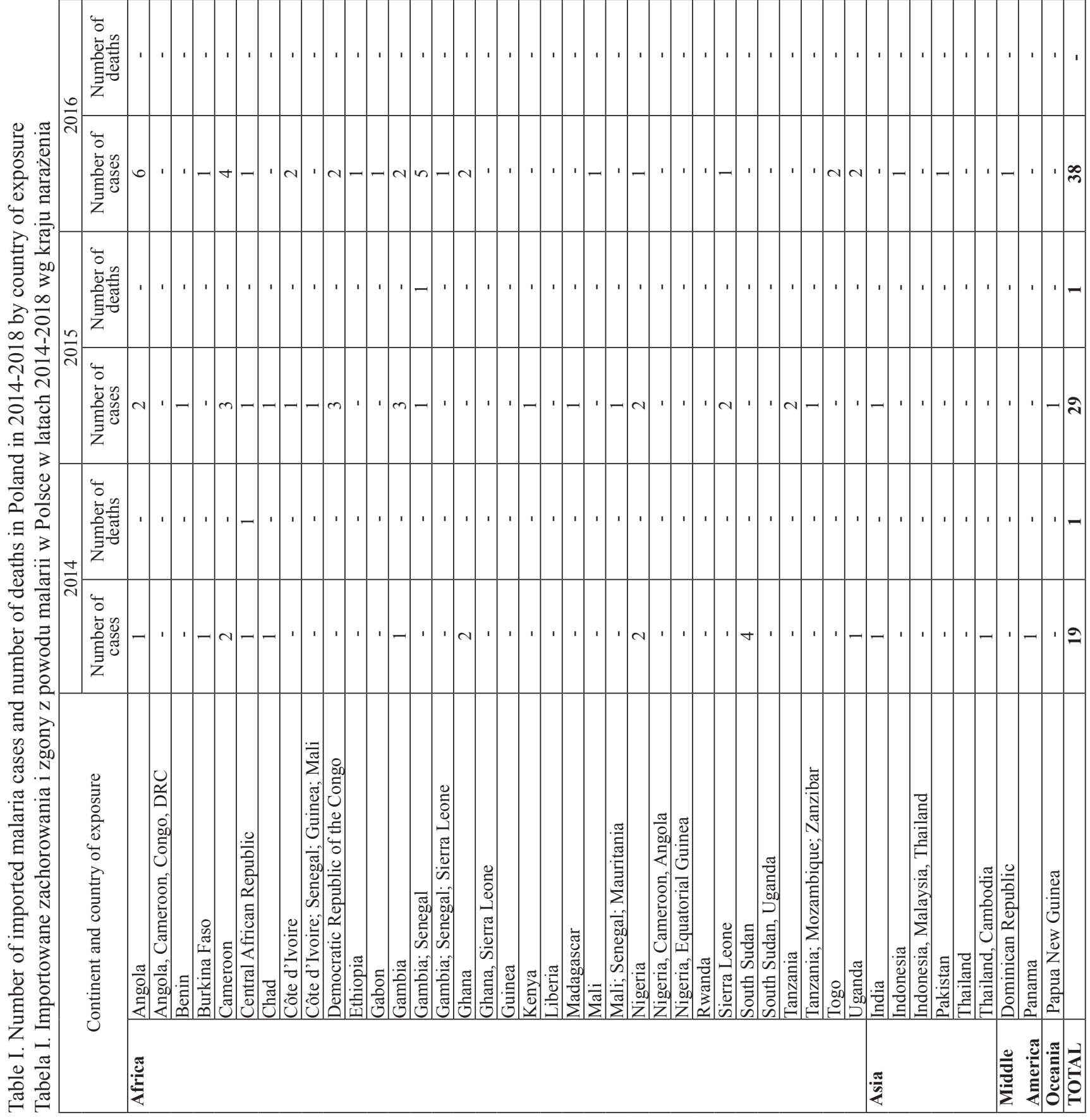


Males accounted for $72 \%$ of all reported cases (the M: F ratio was 2.5: 1), age of the patients ranged from 18 to 74 years, most cases occurred in the age group of 21-30 and the median age was 38 years. As compared to previous years, there were more cases among young people aged $21-30$ (32\% in $2014-2018$ vs. $28 \%$ in 2009-2013) and fewer cases among people over 50 years of age (16\% vs. $26 \%)$.

All cases were classified as imported from endemic malaria areas. In one case, the classification was disputable due to a long diagnostic delay - more than a year after returning from the countries of East Africa. In this case $P$. vivax was identified as a causal agent, and the diagnosis was probably related to relapse, not the primary infection $(9,10)$. The mean time of diagnostic delay in relation to the date of symptoms onset was 6 days. In the calculation of the mean delay of diagnosis two cases were not taken into account - the above-mentioned probable relapse of $P$. vivax malaria and relapse of malaria caused by $P$. ovale, which occurred after 3 months from the first symptoms in the country of exposure.

Clinical characteristics. In total, in three cases the onset of symptoms in Poland were probably relapses of $P$. vivax or $P$. ovale malaria (no documentation of previous diagnosis and treatment). In five cases caused by $P$. falciparum, symptoms have recurred in Poland after previous ineffective treatment in the country of exposure.

In three people, co-infection with the dengue virus was confirmed. In 2014, in two people who were finally confirmed to have malaria, Ebola Virus Disease was suspected in connection with the stay in Nigeria during a confirmed Ebola transmission in that country.

In total, 138 out of 141 patients $(98 \%)$ were hospitalized. In 2015, three people originating in malaria endemic countries in Africa or those living there permanently received only outpatient treatment due to refusal of hospitalization (in one case) and return to their country of residence. In all three cases malaria caused by $P$. falciparum was confirmed.

In 42 patients (30\%) the course of the disease was severe, including three cases caused by $P$. vivax or mixed invasion without $P$. falciparum, as in the case of a patient who refused hospitalization. In the latter case no data on the disease's outcome.

Deaths due to malaria were recorded in three of the five analyzed years: one each in 2014 and 2015 and three deaths in 2018. (Table 1), case fatality in the analyzed period was $3.6 \%$ (5/140 cases of known outcome). Two out of five individuals who died were not Poles. They were: a citizen of the Philippines a crew member on a ship that has arrived from Liberia and a citizen of India temporarily staying in Poland. All fatal cases were acquired in Africa, in four cases the etiological agent was $P$. falciparum and in one case the species of Plasmodium was not determined.
Liczba zachorowań zarejestrowanych w 2016 r. (38 przypadków) osiągnęła najwyższą wartość w ciągu ostatnich 20 lat, podobne wartości odnotowano w przeszłości tylko w 1997 i 1998 roku (odpowiednio 37 i 38 zachorowań). Mediana liczby zachorowań w latach 2014-2018 wynosiła 28, w porównaniu do 22 w poprzednim okresie 5-letnim (2009-2013), co oznacza wzrost o $27 \%$ w stosunku do mediany 2009-2013.

Wśród zgłoszonych zachorowań mężczyźni stanowili 72\% (stosunek M:K wynosił 2,5:1), wiek chorych wahał się od 18 do 74 lat, najwięcej zachorowań wystąpiło w grupie wieku 21-30 lat, mediana wieku wynosiła 38 lat. W porównaniu z wcześniejszymi latami odnotowano więcej zachorowań wśród ludzi młodych w wieku $21-30$ lat (32\% w latach $2014-2018$ vs $28 \%$ w latach 2009-2013) oraz mniej zachorowań wśród osób po 50 r. ż. (16\% vs $26 \%)$.

Wszystkie zachorowania zostały zakwalifikowane jako przypadki importowane (zawleczenia) z krajów endemicznego występowania malarii. W jednym przypadku kwalifikacja przypadku jako zawleczenia budziła wątpliwości w związku z dużym opóźnieniem rozpoznania - kilkanaście miesięcy po powrocie z krajów Afryki Wschodniej. Jako czynnik etiologiczny w tym przypadku rozpoznano $P$. vivax, a rozpoznanie dotyczyło prawdopodobnie nawrotu, a nie pierwszego rzutu choroby $(9,10)$. Średni czas opóźnienia rozpoznania w stosunku do daty wystąpienia pierwszych objawów wynosił 6 dni. W obliczeniu średniego czasu opóźnienia rozpoznania nie uwzględniono dwóch zachorowań - w/w prawdopodobnego nawrotu malarii vivax oraz nawrotu malarii wywołanej przez $P$. ovale, który wystąpił po 3 miesiącach od pierwszych objawów w kraju narażenia.

Charakterystyka kliniczna zachorowań. Ogółem w trzech przypadkach wystąpienie objawów w Polsce było prawdopodobnie nawrotem malarii vivax lub ovale (brak dokumentacji wcześniejszego rozpoznania i leczenia). W pięciu przypadkach wywołanych przez $P$. falciparum doszło do nawrotu objawów w Polsce po wcześniejszym nieskutecznym leczeniu w kraju narażenia.

U trzech osób potwierdzono jednoczesne zakażenie wirusem dengi. W 2014 r. u dwóch osób, u których ostatecznie potwierdzono malarię, podejrzewano ebolę w związku z pobytem w Nigerii w okresie potwierdzonej transmisji wirusa ebola w tym kraju.

Ogółem hospitalizowano 138 spośród 141 chorych (98\%). W 2015 r. trzy osoby pochodzące z krajów endemicznego występowania malarii (w Afryce) lub mieszkające tam na stałe otrzymały leczenie ambulatoryjnie w związku z odmową hospitalizacji (w jednym przypadku) i powrotem do kraju zamieszkania, u wszystkich trzech potwierdzono malarię wywołaną P. falciparum. 
Laboratory confirmations. In 127 cases $(90 \%)$ the diagnosis of malaria was confirmed by blood films microscopy (including one examination performed postmortem), in 9 cases (6\%) the only confirmation was the result of a rapid immunochromatographic test, remaining 5 cases were confirmed using PCR . A total of 43 patients were tested with rapid tests (RDTs), of which four were negative - the diagnosis of malaria in these cases was based on the blood films microscopy results.

Species of Plasmodium was determined in 127 cases (90\%), including 7 cases confirmed exclusively on the basis of RDT. Most cases were caused by P. falciparum (78\%, 99/127), the second most frequent species was $P$. vivax $(13 \% ; 17 / 127)$ (Table II). In six cases a mixed invasion was diagnosed, in five of them $P$. falciparum was one of the species. Most of the cases caused by P. falciparum (98\%, 97/99) were imported from Africa (Table II).
U 42 chorych $(30 \%)$ przebieg choroby określono jako ciężki, w tym w trzech przypadkach wywołanych $P$. vivax lub inwazją mieszaną bez udziału $P$. falciparum, oraz w przypadku pacjenta który odmówił hospitalizacji. W tym ostatnim przypadku brak danych o zejściu choroby.

Zgony z powodu malarii odnotowano $\mathrm{w}$ trzech $\mathrm{z}$ pięciu analizowanych lat: w 2014, 2015 oraz w 2018 r. (odpowiednio po jednym i trzy zgony) (Tab. I), śmiertelność w analizowanym okresie wynosiła 3,6\% (5/140 zachorowań o znanym zejściu). Dwie spośród pięciu zmarłych osób nie były Polakami. Byli to: obywatel Filipin, będący członkiem załogi statku, który przypłynął z Liberii oraz obywatel Indii przebywający czasowo w Polsce. Wszystkie zachorowania zakończone zgonem zostały nabyte w krajach Afryki, w czterech przypadkach czynnikiem etiologicznym był zarodziec sierpowaty P. falciparum, w jednym nie określono gatunku zarodźca.

Table II. Number of imported malaria cases in Poland in 2014-2018 by continent of exposure and species of Plasmodium Tabela II. Importowane zachorowania na malarię w Polsce w latach 2014-2018 wg kontynentu narażenia i gatunku Plasmodium

\begin{tabular}{|c|c|c|c|c|c|c|c|c|c|}
\hline \multirow{2}{*}{\multicolumn{2}{|c|}{ Year \& continent of exposure }} & \multirow{3}{*}{ 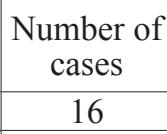 } & \multicolumn{6}{|c|}{ Species of Plasmodium } & \multirow{3}{*}{\begin{tabular}{|c}
$\begin{array}{c}\text { Number of } \\
\text { deaths }\end{array}$ \\
1 \\
\end{tabular}} \\
\hline & & & \multirow{2}{*}{$\begin{array}{c}\text { falciparum } \\
13\end{array}$} & \multirow{2}{*}{$\begin{array}{c}\text { vivax } \\
-\end{array}$} & \multirow{2}{*}{$\begin{array}{c}\text { ovale } \\
2\end{array}$} & \multirow{2}{*}{$\begin{array}{c}\text { malariae } \\
-\end{array}$} & \multirow{2}{*}{$\begin{array}{c}\text { mixed } \\
1\end{array}$} & \multirow{2}{*}{$\frac{\mathrm{spp}}{-}$} & \\
\hline \multirow{3}{*}{2014} & Africa & & & & & & & & \\
\hline & Asia & 2 & - & 1 & - & - & - & 1 & - \\
\hline & Middle America & 1 & - & 1 & - & - & - & - & - \\
\hline \multirow{3}{*}{2015} & Africa & 27 & 24 & - & 1 & - & 1 & 1 & 1 \\
\hline & Asia & 1 & - & 1 & - & - & - & - & - \\
\hline & Oceania & 1 & - & 1 & - & - & - & - & - \\
\hline \multirow{3}{*}{2016} & Africa & 35 & 22 & 1 & 1 & - & 2 & 9 & - \\
\hline & Asia & 2 & - & 2 & - & - & - & - & - \\
\hline & Middle America & 1 & 1 & - & - & - & - & - & - \\
\hline \multirow{2}{*}{2017} & Africa & 22 & 18 & 2 & - & - & 1 & 1 & - \\
\hline & Asia & 5 & 1 & 3 & - & - & 1 & - & - \\
\hline \multirow{2}{*}{2018} & Africa & 25 & 20 & 2 & 1 & - & - & 2 & 3 \\
\hline & Asia & 3 & - & 3 & - & - & - & - & - \\
\hline \multicolumn{2}{|c|}{ TOTAL } & 141 & 99 & 17 & 5 & - & 6 & 14 & 5 \\
\hline
\end{tabular}

Countries of exposure. In all cases of malaria registered in 2014-2018, the probable area of acquisition was established. $89 \%$ of malaria cases were acquired in Africa and 9\% - in Asia (Table I). 10 cases been acquired while traveling to more than one endemic country - in these cases, infection could be acquired in each of the countries visited (Table I). Cameroon was the country where the highest number of cases were acquired, and next - Nigeria, which for many years has been mentioned as the place of acquisition of the largest number of cases registered in Poland.

Compared to previous years, the number of cases acquired outside Africa decreased - in 2009-2013 malaria cases acquired in Asian countries accounted for $24 \%$ of all cases (versus $9 \%$ in 2014-2018), and acquired in South America 5.5\% (in 2014-2018 no cases acquired in South America).

Purpose of travel. Overall, purpose of travel was determined in 124 out of 141 reported cases (88\%). Most of trips to endemic malaria countries were
Potwierdzenia laboratoryjne malarii. W 127 przypadkach (90\%) rozpoznanie malarii zostało potwierdzone w badaniu mikroskopowym rozmazów krwi obwodowej (w tym jedno badanie wykonane pośmiertnie), w 9 przypadkach (6\%) jedynym potwierdzeniem był wynik szybkiego testu immunochromatograficznego, w pozostałych 5 potwierdzenie malarii uzyskano w badaniu PCR. Ogółem badanie szybkimi testami wykonano u 43 osób, z czego u czterech uzyskano wynik ujemny - rozpoznanie malarii u tych chorych postawiono na podstawie wyniku rozmazu.

Gatunek Plasmodium określono w 127 przypadkach (90\%), w tym w 7 zachorowaniach potwierdzonych wyłącznie na podstawie badania szybkim testem. Większość zachorowań została wywołana przez P. falciparum (78\%; 99/127), drugim pod względem częstości gatunkiem był P. vivax $(13 \%$; 17/127) (Tab.II). W sześciu przypadkach rozpoznano inwazję mieszaną, $\mathrm{w}$ tym $\mathrm{w}$ pięciu $\mathrm{z}$ udziałem P. falciparum. Większość zachorowań wywołanych przez P. falciparum $(98 \%$; 97/99) została zawleczona z krajów Afryki (Tab. II). 
for tourism $(45 \%, 56 / 124)$, traveling for business accounted for a similar proportion $(43 \%, 53 / 124)$. Among tourist trips can be observed changes related to current tourist destinations trends - over $30 \%$ of cases in this group were acquired during trips to Gambia and Senegal, which were rarely mentioned before. Among those travelling for work-related purposes the number of volunteers of a humanitarian organisation and humanitarian missions attendees increased (9/53). A separate group constitute members of crews of ships or planes - in the analysed period, 6 seamen with malaria were registered, including one fatal case. People originating from countries endemic for malaria accounted for $18 \%(26 / 141)$ of all patients, among them were 12 people living for a long time in Poland who travelled to their country of origin to visit family or friends (VFR) $(10 \% ; 12 / 124)$, one person starting studies in Poland and 7 people travelling in connection with their work. In the remaining cases, there is no data for the purpose of travelling.

Chemoprophylaxis use. Information on the use of chemoprophylaxis was obtained from 124 people (88\%). Among them, 21 people reported taking chemoprophylaxis, most of them were nonadherent with regimen - the most common mistake was the lack of regularity in taking, missed doses or stopping use the medication too early. People who used any chemoprophylaxis mostly travelled for business. One patient who travelled to Papua New Guinea fell ill despite taking the recommended antimalarial drug with adherence to chemoprophylaxis regimen. 17 people did not answer the question about the use of malaria chemoprophylaxis.

\section{DISCUSSION AND CONCLUSIONS}

The total number of imported malaria cases increased in comparison with previous years, but still remains at a low level. No locally acquired cases were recorded. Among the total number of imported cases, the predominance of people traveling for tourism or business is still observed. The proportion of people from endemic malaria countries (immigrants, students) who have been infected during visit in the country of origin remains low in comparison to Western European countries, where persons of this group accounted for $30 \%$ to $80 \%$ of all cases (4).

Persons from endemic countries, visiting their country of origin seem to be at higher risk of acquiring malaria than those traveling for other purposes, although the clinical course of malaria in this group may be milder.

In the observed 5-year period, high fatality rate due to malaria was reported, although deaths did not occur in all years - in Poland case fatality rate was
Kraje narażenia. We wszystkich przypadkach malarii zarejestrowanych w latach 2014-2018 ustalono prawdopodobny obszar, na którym doszło do zarażenia. W 89\% do zarażenia doszło w krajach Afryki, w 9\% - w krajach Azji. (Tab. I). Do 10 zachorowań doszło po powrocie z podróży, które obejmowały więcej niż jeden kraj endemicznego występowania malarii - w tych przypadkach do zarażenia mogło dojść w każdym z odwiedzanych krajów (Tab. I). Krajem, w którym doszło do największej liczby zarażeń był Kamerun, w drugiej kolejności - Nigeria, która od wielu lat jest wymieniana jako miejsce nabycia największej liczby zachorowań na malarię występujących w Polsce. W porównaniu z wcześniejszymi latami zmniejszył się udział zachorowań nabytych poza Afryką - w latach 20092013 malaria nabyta w krajach Azji stanowiła 24\% wszystkich zachorowań (versus 9\% w latach 2014-2018), a nabyta w krajach Ameryki Płd. 5,5\% (w latach 2014-2018 brak zawleczeń z Am. Płd.).

Cel podróży. Ogółem cel podróży ustalono w 124 spośród 141 zgłoszonych zachorowań (88\%). Większość wyjazdów do krajów endemicznych malarii miała charakter turystyczny $(45 \%$; 56/124), wyjazdy związane z pracą stanowily podobny odsetek $(43 \%, 53 / 124)$. W grupie wyjazdów turystycznych można zaobserwować zmiany związane $\mathrm{z}$ aktualnymi kierunkami w ruchu turystycznym - ponad 30\% zachorowań w tej grupie zostało nabytych podczas wyjazdów do Gambii i Senegalu, które wcześniej rzadko były wymieniane przez turystów. Wśród osób wyjeżdżających w związku z pracą wzrosła liczba zachorowań wolontariuszy pracujących w ramach organizacji oraz misji humanitarnych $(9 / 53)$. Odrębną grupę stanowią członkowie załóg statków lub samolotów - w analizowanym okresie odnotowano zachorowania 6 marynarzy, w tym jedno zakończone zgonem. Osoby pochodzące $z$ krajów endemicznych dla malarii stanowity $18 \%(26 / 141)$ wszystkich chorych w analizowanym okresie, wśród nich 12 osób mieszkających od dłuższego czasu w Polsce, które podróżowały do kraju pochodzenia w celu odwiedzin rodziny i przyjaciół (10\%; 12/124), jedna osoba rozpoczynająca studia w Polsce oraz 7 osób podróżujących w związku z wykonywaną pracą. O pozostałych brak danych co do celu podróżowania.

Chemioprofilaktyka malarii. Informację o stosowaniu chemioprofilaktyki uzyskano od 124 osób (88\%). Wśród nich 21 osób stosowało profilaktykę lekową, większość przyjmowała leki niezgodnie z zaleceniami. Najczęściej popełnianym błędem był brak regularności w przyjmowaniu, pominięcie dawki lub zbyt wczesne przerwanie przyjmowania leku. Osoby, które stosowały jakąkolwiek chemioprofilaktykę w większości należały do grupy podróżujących w związku z pracą. Jedna osoba podróżująca turystycznie do Papui Nowej Gwinei zachorowała pomimo przyjmowania właściwego leku zgodnie z zaleceniami. 17 osób nie udzieliło odpowiedzi na pytanie o leki p/malarii przyjmowane profilaktycznie. 
$3.6 \%$ compared with $0.8 \%$ in the EU / EEA countries in cases with known outcome in 2016. At the same time, the incidence of malaria in Poland was about 10fold lower than in the EU / EEA countries. (1). Such large differences in deaths between Poland and other EU / EEA countries were observed earlier. In addition to the structure of population of malaria patients, an important factor affecting the clinical course and the outcome of the disease is time to start the appropriate treatment (11).

The number of diagnostic delays in Poland is still high (over $75 \%$ diagnoses after 3 days from the onset of symptoms) and the situation in this area is not improved despite spreading information on the risk of malaria before each travelling season.

It is particularly important to direct the information to the primary care physicians because the most diagnostic delays and delays in referrals to appropriate specialist care occur in primary care.

\section{REFERENCES}

1. European Centre for Disease Prevention and Control. Malaria. In: ECDC. Annual epidemiological report for 2016. Stockholm: ECDC; 2019. Available at: https://ecdc.europa.eu/en/annual-epidemiological-reports

2. European Centre for Disease Prevention and Control. Multiple reports of locally-acquired malaria infections in the EU - 20 September 2017. Stockholm: ECDC; 2017 Available at: https:// ecdc.europa.eu/en/publications-data/rapid-risk-assessment-multiple-reports-locally-acquired-malaria-infections-eu

3. Hospital-acquired malaria infections in the European Union - 30 April 2018, Stockholm, 2018. Available at: https://ecdc.europa.eu/en/publications-data/rapid-risk-assessment-hospital-acquired-malaria-infections-european-union

4. Assessing the burden of key infectious diseases affecting migrant populations in the EU/EEA. ECDC technical report. Stockholm, May 2014. doi: $10.2900 / 28792$

5. Infectious Diseases and Poisonings in Poland in 2014 - 2017; Bulletins of the National Institute of Public Health and Chief Sanitary Inspectorate: Warszawa, 2015- 2018.

6. Stępień M. Malaria in Poland in 2013. Przegl Epidemiol 2015; 69(2):273- 275

7. Ustawa $z$ dnia 5 grudnia 2008 r. o zapobieganiu oraz zwalczaniu zakażeń i chorób zakaźnych u ludzi. Dz.U. 2008 nr 234 poz. 1570. Available at: http://prawo.sejm.gov.pl/isap.nsf/DocDetails. xsp?id=WDU20082341570

\section{OMÓWIENIE WYNIKÓW I PODSUMOWANIE}

Całkowita liczba importowanych zachorowań na malarię wzrosła w porównaniu z poprzednimi latami, jednak nadal utrzymuje się na niskim poziomie. Nie odnotowano żadnego przypadku rodzimego. Wśród ogółu zawleczonych zachorowań w Polsce w dalszym ciągu obserwuje się przewagę osób podróżujących turystycznie lub w związku z pracą. Udział osób pochodzących z krajów endemicznego występowania malarii (imigrantów, studentów), które uległy zarażeniu podczas odwiedzin w kraju pochodzenia pozostaje niski w porównaniu do krajów Europy Zachodniej, gdzie udział zachorowań osób z tej grupy wynosi 30$80 \%$ (4). Ryzyko zarażenia malarią osób pochodzących z krajów endemicznych podczas wizyt w kraju pochodzenia jest wyższe niż osób podróżujących w innych celach, chociaż przebieg kliniczny malarii $\mathrm{w}$ tej grupie może być łagodniejszy.

W obserwowanym okresie 5-letnim odnotowano wysoką śmiertelność z powodu malarii, chociaż nie we wszystkich latach występowały przypadki śmiertelne - śmiertelność wynosiła 3,6\% w porównaniu z 0,8\% wśród przypadków malarii o znanym zejściu na obszarze EU/EEA w 2016 r., przy zapadalności ok. 10-krotnie mniejszej niż średnia w krajach EU/EEA (1). Tak duże różnice na niekorzyść naszego kraju były obserwowane już wcześniej. Poza strukturą populacji osób chorujących istotnym czynnikiem wpływającym na przebieg kliniczny i zejście choroby jest czas podjęcia właściwego leczenia (11).

Liczba opóźnionych rozpoznań malarii w Polsce jest nadal wysoka (ponad 75\% rozpoznań po upływie 3 dni od początku objawów) i sytuacja w tym zakresie nie ulega poprawie mimo upowszechniania informacji o możliwości zarażenia przed każdym sezonem wyjazdowym.

Szczególnie ważne jest kierowanie odpowiedniej informacji do lekarzy POZ, ponieważ najwięcej opóźnień w rozpoznawaniu i kierowaniu do odpowiednich ośrodków występuje w podstawowej opiece zdrowotnej.

8. Definicje przypadków chorób zakaźnych na potrzeby nadzoru epidemiologicznego stosowane $\mathrm{w}$ latach 2014-2017 (63 definicje). Zakład Epidemiologii NIZP-PZH, styczeń 2014. Available at: http://wwwold.pzh.gov.pl/oldpage/epimeld/inne/ Def_PL2_3.pdf

9. Durante Mangoni E, Severini C, Menegon M, Romi R, Ruggiero G, Majori G. Case report: An unusual late relapse of Plasmodium vivax malaria. J Trop Med Hyg. 2003 Feb;68(2):159-60. 
10. White NJ. Determinants of relapse periodicity in Plasmodium vivax malaria. Malar J. 2011 Oct 11;10:297. doi: 10.1186/1475-2875-10-297.

11. Stępień M, Rosińska M. Imported malaria in Poland 2003 to 2011: implications of different travel patterns. J Travel Med. 2014 May-Jun;21(3):189-94. doi: $10.1111 / \mathrm{jtm} .12109$.
Received: 29.03.2019

Accepted to publication: 10.04.2019

Otrzymano: 29.03.2019 r.

Zaakceptowano do publikacji: 10.04.2019 r.

\section{Address for correspondence:}

Adres do korespondencji:

Małgorzata Stępień

National Institute of Public Health - National Institute of Hygiene

Department of Epidemiology of Infectious Diseases and Surveillance

Chocimska 24

00-791 Warsaw, Poland

tel. (022) 5421-248

e-mail: mstepien@pzh.gov.pl 